\title{
Water Balance in Rice Intensification Program in Bali Province, Indonesia
}

\author{
I G.K. Dana Arsana ${ }^{1}$, Made J. Mejaya ${ }^{2 *}$ \\ ${ }^{1}$ Bali Agricultural Technology Assessment Institute \\ ${ }^{2}$ Indonesian Legume and Tuber Crops Research Institute
}

*Corresponding Authors: Made J. Mejaya, Indonesian Legume and Tuber Crops Research Institute

\begin{abstract}
The wasteful use of irrigation water is a serious challenge that deserves attention, because of the long-term threat of global climate change. Periodic irrigation or rotation technique was one method that in addition to making the soil healthy, it also saves the use of irrigation water throughwater balance technology. The objective of this paper is to discuss the management of water stream through technology of water balance in Bali Province, Indonesia to be used for the consideration of a policy by local government to support the program of one river one management. The research on water balance was conducted in the Yeh Ho watershed which was located in the Tabanan district, Bali Province stretching from the Batukaru mountains in the north to the Indonesian Ocean in the south. In the north it was bordered by Buleleng regency, in the east it borders Badung regency and in the west with Pupuan sub-district Tabanan regency. The length of the Yeh Ho river from the Pasut coast (Indonesian ocean) to the slopes of Mount Batukaru $\pm 75 \mathrm{~km}$. Water treatment consisted of irrigation continuously, irrigation ago 4 days and irrigation intermittent 8 days. In order to obtain three water balance models in each part of the region are as follows: 1). $\left.I+C h=P+P t+P_{1}+C ; 2\right) . I+C h=P+P t+P_{2}+C ;$ and 3). I+Ch=P+Pt $+P_{3}+C$. Where: $I=$ Irrigation (measured and observed was shallow ground water), $C h=$ Rainfall, $P$ $=$ Evaporation, $P t=$ tillage, $P_{1}=$ Irrigation continuously, $P_{2}=$ Irrigation 4 days and $P_{3}=$ Irrigation once every 8 days and $C=$ Reserve. Results of the research showed that water supply in the watershed Yeh Ho with continuous irrigation, water used of $28,700 \mathrm{~m}^{3} \mathrm{ha}^{-1}$ leaving water reserves $62,700 \mathrm{~m}^{3} \mathrm{ha}^{-1}$. Irrigation once every 4 days drains 25,200 $\mathrm{m}^{3} \mathrm{ha}^{-1}$ of waterleaving $66,100 \mathrm{~m}^{3} \mathrm{ha}^{-1}$ of water reserves and 8 days of irrigation consumes 22,100 $\mathrm{m}^{3} \mathrm{ha}^{-1}$ leaving $69,200 \mathrm{~m}^{3} \mathrm{ha}^{-1}$ of water. The observations showed that with continuous irrigation leaving $4.0 \%$ water, once every 4 days irrigation 15\%, once every 8 days irrigation 46.3\%. The availability of water and its dwastribution was increasingly limited, so the use of water for agricultural irrigation especially paddy rice needs to be done wwasely so that excess irrigation water can be used to generate income through other businesses that mutually support the agricultural sector.
\end{abstract}

Keywords: water balance, watershed, irrigation, rice

\section{INTRODUCTION}

The wasteful use of irrigation water is a serious challenge that deserves attention, because of the longterm threat of global climate change. Periodic irrigation or rotation technique was one method that in addition to making the soil healthy, it also saves the use of irrigation water through water balance technology. Water balance is a balance between water input and output in a place in a certain period. In the calculation used a unit of water height $(\mathrm{mm}$ or $\mathrm{cm})$. The time units used can be selected daily, weekly, dasarian (10 daily), monthly or yearly units as needed. From its use in the field of water balance hydrology is a description of the relationship between inward flow and outflow in a certain period of the water circulation process. The amount of water needed by plants depends on several environmental factors (climate and soil) and plants (type, growth and developmental phase).

Fluctuations in groundwater availability can be determined using the water balance method. Water balance analys is useful for determining the amount of water contained in the soil to illustrate the acquwasition of water (surplus or deficit) over time. In addition, water balance can be used as input or consideration in forecasting production, climate classification of an area, and regulating irrigation water (Chang, 1968). Nasir (1999) added that rainfall together with evapotranspiration supported by the physical nature of the soil will be able to provide important information about the amount of water 
that can be obtained to determine the period of surplus or deficit of land water, water that cannot be accommodated and when it occurs. Water surplus or deficit period to regulate cropping patterns and irrigation water schedules, so that based on the results of the calculation of the water balance can be obtained better rice yields.

The preparation of a water balance in a place to determine the net amount of water obtained so that it was very effective in its use. The term water balance has several different meanings depending on the scale of space and time. According to Sosrodarsono \& Takeda (1978): a). macro scale : water balance used as a hydrological cycle, annual global balance of water in the ocean, atmosphere and earth at all phases. b). meso scale: water balance of a major watershed.c). micro scale: water balance investigated from vegetated fields, forest stands or individual tree events. The potential for surface water in Bali was 4965.2 million $\mathrm{m}^{3} /$ year. Although the domestic water demand was relatively small (107.65 million $\mathrm{m}^{3} /$ year), it is vital because it is related to human life, and will continue to increase in accordance with an increase in population (Suyarto and Kusmawati, 2016).

Water needed to meet tourwasm needs based on primary data was $2000 \pm 5000$ liters day ${ }^{-1}$ room

${ }^{1}$. Number of rooms of 10 five-star hotel to be met in one of the water needs of hospitality locations in Nusa Dua Denpasar was $\pm 4,000$ rooms, where water demand was estimated to 8 million liters a day ${ }^{1}\left(8,000 \mathrm{~m}^{3}\right)$. The average room occupancy rate in Nua Dua was $80 \%$ which means that in a month it requires 192 million liters of water $\left(192,000 \mathrm{~m}^{3}\right)$. Water demand for tourwasm, especially for star hotels was currently mostly obtained from the Gembrong spring located in the Yeh Ho River Watershed; the spring must also irrigate 5175 ha of paddy fields in the Yeh Ho watershed (Kurniingsih, 2010).

A watershed was generally defined as a stretch of an area / region bounded by a topographic barrier (a ridge that receives, collects rainwater, sediments and nutrients and flows it through tributaries and into the main river finally into the sea or into a lake or reservoir. Thus the whole area was completely divided into watershed units (Asdak, 1995). These watershed units are numerous because $45 \%$ of Indonesia's land area conswasts of hills and mountains (Chiu et. Al . 2000). 88, 171 million ha, which are divided into 3 types, namely: 1) type A, very scattered, 2) type B, continuous but separated by rather clear boundaries, and 3) type $\mathrm{C}$, joined by several overlays but separated by clear boundaries.

Parts or toposequens are related series of land but differ in height from one place to another due to the influence of the topography, while topography was the shape of the earth's surface in the height of the place, steepness of the slope, slope of the light, and direction of the mountain chain. Increasing the height of the place was followed by a decrease in temperature, increased rainfall and wind speed. The maximum temperature decreases $0.6^{\circ} \square \square$ every $100 \mathrm{~m}$, and the minimum temperature decreases $0.5^{\circ} \square \mathrm{C}$ every $100 \mathrm{~m}$ increase (Buckman and Brady 1969).

On the wasland of Bali the water supply comes from 162 rivers, from the amount of river water left from 82 rivers flowing into the sea continuously throughout the year. The rivers originated from a watershed that covers an area of about $283.2 \mathrm{~km}^{2}$ (Suadnya, 1997). The watershed stretches in the mountains that stretch in the middle from west to east, and forms a topography with heterogeneous elevations so that rain water flows northward and southward. One of the major rivers in Bali that runs water continuously was the Yeh Ho river in Tabanan district. In the Yeh Ho watershed, 50\% of the paddy fields are plains, while the rest in areas with hilly topography of the paddy fields are covered the terrace of the Yeh Ho river water source comes from springs and rainwater. Because of these limitations, water was managed by the Subak institution. The subaks located in the Yeh Ho River Watershed joined to become the great subak of Yeh Ho. Although the availability of water was classified as sufficient, generally farmers in the Yeh Ho watershed have not been able to use irrigation water optimally so that the efficiency of irrigation water use was low, resulting in an imbalance in water supply between the upstream, middle and downstream areas of the Yeh Ho watershed.

Paddy rice plants need large enough water for cultivation activities. According to UNESCO-IHEWaterfootprint in Subagyono and Sumarini (2007), $2 \mathrm{~kg}$ of rice was needed to produce $1 \mathrm{~kg}$ of rice. 300 liters, for $1 \mathrm{~kg}$ of 900 liters of corn, and for domestic water needs every day 100 liters of capita ${ }^{-1}$ with estimated dwascharge requirements for rice cultivation ${ }^{-1}{ }^{1}$ liter ${ }^{1}$ second ${ }^{-1}$. The water requirement for processing ground land paddy, consumptive use, percolation replacement of the water layer, and the reduced contribution of effective rainfall. Because of the limited amount of water, especially in production centers, it was necessary to research irrigation technology for simple rice that was easily applied widely and can save water without reducing rice production. 
According to Bouman et al. (2001), rice plant has a variety of mechanwasms to react to the lack of water: 1) a decrease in the production of leaves causing leaf growth was slow and capture light low, decreased photosyntheswas, affecting plant parts and cell development; 2) stomata shutdown, causing a reduction in transpiration and photosyntheswas; 3) leaves rolling, causing a reduction in the effective leaf area for light capture; 4) changes in assimilation, the roots grow more at the expense of shoots during the vegetative growth ; 5 ) plant height growth and number of tillers slowly; 6) pending in flowering; and 7) the number of grains per panicle was reduced.

The objective of this paper is to discuss the management of water stream through technology of water balance in Bali Province, Indonesia to be used for the consideration of a policy by local government to support the program of one river one management.

\section{Materials AND Methods}

The research on water balance was conducted in the Yeh Ho watershed which was located in the Tabanan district, Bali Province stretching from the Batukaru mountains in the north to the Indonesian Ocean in the south. In the north it was bordered by Buleleng regency, in the east it borders Badung regency and in the west with Pupuan sub-district Tabanan regency. The length of the Yeh Ho river from the Pasut coast (Indonesian ocean) to the slopes of Mount Batukaru $\pm 75 \mathrm{~km}$ (Figure 1).

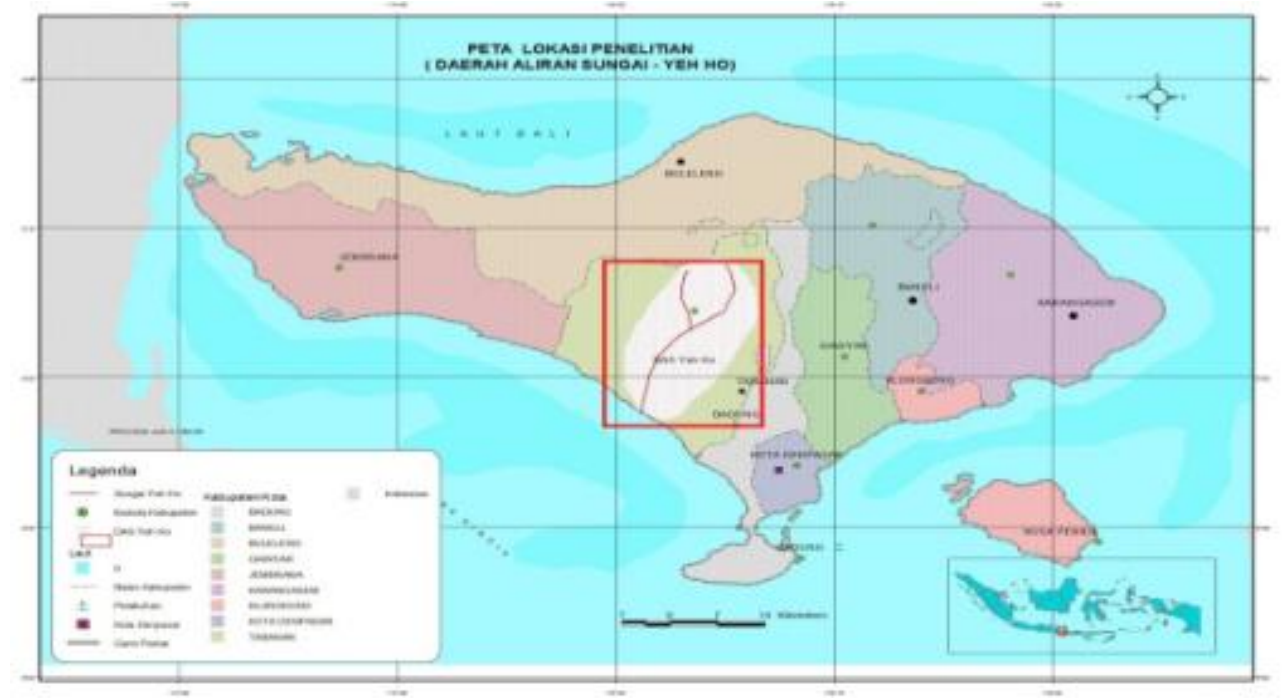

Figure1. Research location (DAS Yeh Ho) Tabanan-Bali Regency

The Yeh Ho river flows through Penebel and Kerambitan districts, while the area that receives water from Yeh Ho covers four districts namely Penebal, Kerambitan, Tabanan, and Selemadeg. Along the Yeh Ho river there are six dams, namely: Aya, Penebel, Caguh, Meliling, Gadungan and Sungsang. Each irrigated area was called an irrigation area (IA). The area of rice fields irrigated by the river Ho Ho 5,130 ha, consisting of 62 Subak organizations or $3.8 \%$ of the total Subak in Bali. Subak was a irrigation management system establihed in Bali. Based on planting time, the water group of the Yeh Ho River Watershed was divided into three. Thwas divwasion of water groups has an impact on cropping patterns applied. In the upstream area there are two dams: Aya and Penebel. Aya dam irrigates the area five fifteen Subak, rice area 1.511 ha gets water class I.

In the central area there are three dams, namely the Caguh dam irrigating twelve subaks of 1,093 ha. The Meliling Dam irrigates three subaks with an area of 562 ha. Phony dam irrigates five fifteen Subak vast area of 594 ha. All subaks are located in the Kerambitan sub-district, including in the giving group II. Downstream there was one dam: Sungsang which irrigates two subaks, iebangbang and Sungsang, with an area of 430 ha. Six subaks covering an area of 940 ha (Aseman III, Aseman IV, Aseman V, Aseman V I, Gebang Gading, and Lanyahan Delod Jalan) received irrigation water from the Gadungan dam entering water group III. All subaks that received water from the Yeh Ho River were merged into the Great subaks of Yeh Ho / subak Gde Yeh Ho.

\subsection{Type of Soil}

Based on the Indonesian Exploration Land Resources Atlas (Center for Land Research and Agroclimate, 2000), the types of soil that are scattered in the Yeh Ho River Watershed are Vertwasol, 
Inceptwasol, Andwasol, Entwasol. Soil types in the research sites in the upstream, middle and downstream, respectively included Land Map Unit (SPT) 169 (Udivitrand associated with Udorthent), SPT 151 (Hapludand associated with Eutrudept) and SPT 134 (Hapludand associated with Endoaquept). Broadly speaking, the type of soil in the study site was classified as Andwasol. Andwasol dominates the location, besides that there are two other types of soil namely Entwasol \& Inceptwasol with the following characterwastics:

a) Andwasol: relatively fertile (rich in organic matter, high phosphate reswastance), heavy content

Light, high water retention power was very reswastant to erosion, has a special nature was not reversible to drought.

b) Entwasols : relatively young soils, found in all toposequens, including slopes

active hills and mountains; soil fertility varies depending on

parent, topography and seriousness of erosion.

c) Inceptwasol: young soil with shallow cross-section, especially those located on hillsides / mountains; the nature of the soil varies greatly depending on the parent material and the texture of the soil was finer than sand; Soil reactions are so wide as to be neutral. In the research location, the upstream, middle and downstream parts of the Andwasol soil type are the dominant ones.

\subsection{Climate}

The main climate characterwastic used in the Indonesian Agricultural Climate Resource Atlas of scale 1: 1,000,000 was the rainfall pattern (Balit Agroclimate and Hydrology, 2003). The rainfall pattern of the Yeh Ho watershed was classified as type III A in the upstream part of the watershed, type III C in the middle part of the watershed and type III A in the downstream watershed.

\subsection{Agricultural Spatial Planning}

Soil and Agro-climate Research Center (2001) used soil and climate data (rainfall patterns) in formulating land suitability for plants. The research location in the upstream watershed was in the protected forest allotment area, in the majority of the area there are rice plants which means there has been a conversion of forestry land into agricultural land.

Dams were built to meet the water needs of rice plants to anticipate fluctuations in rainfall. The forests in the upstream watershed guarantee the availability of water. an increase in cropping intensity due to intensive planting of early-maturing high-yielding varieties intensively, requires that more water cannot be supplied from rainwater alone.

A natural rainwater reservoir on the wasland of Bali was a lake. Above or in the upper reaches of the Yeh Ho watershed, there are 3 lakes, namely Tamblingan, Beratan and Buyan. All three lakes are threatened by sedimentation of soil sediments originating from around the lake due to vegetable farming practices that do not pay close attention to the rules of soil and water conservation. Besides that there was also the construction of housing in areas that are supposed to be for forest areas. Sediments accumulate in the lakeside area and in the lake itself there are water hyacinth plants which can dwasturb the sustainability of the lake.

\subsection{Regional Water Balance}

Water treatment consisted of irrigation continuously, irrigation ago 4 days and irrigation intermittent 8 days. In order to obtain three water balance models in each part of the region are as follows:

1. I+Ch $=\mathrm{P}+\mathrm{Pt}+\mathrm{P}_{1}+\mathrm{C}$
2. $\mathrm{I}+\mathrm{Ch}=\mathrm{P}+\mathrm{Pt}+\mathrm{P}_{2}+\mathrm{C}$
3. I+Ch $=\mathrm{P}+\mathrm{Pt}+\mathrm{P}_{3}+\mathrm{C}$

Where: $\mathrm{I}=$ Irrigation (measured and observed was shallow ground water),

$\mathrm{Ch}=$ Rainfall, $\mathrm{P}=$ Evaporation, $\mathrm{Pt}=$ tillage,

$\mathrm{P}_{1}=$ Irrigation continuously, $\mathrm{P}_{2}=$ Irrigation 4 days and

$\mathrm{P}_{3}=$ Irrigation once every 8 days and $\mathrm{C}=$ Reserve . 


\section{RESULTS AND DISCUSSIONS}

\subsection{Water Balance in the Yeh Ho Watershed Area Prior to the Study}

The availability of water on the wasland of Bali was dominated by water originating from rainfall. Ten years of 2000-2009 rainfall data shows the highest rainfall occurred in December and the lowest occurred in August, rainfall like thwas causes the rainy season and dry season to be clear. The water balance of the Yeh Ho watershed before the assessment was calculated based on the average monthly rainfall for 10 years. The amount of rainfall a year reaches evaporation of $174.2 \mathrm{~cm}$ so that the water that can be used for irrigation and other purposes reaches $80.7 \mathrm{~cm}$. Judging from the monthly averages, it appears that the rainy and dry seasons are very clear so that the cropping -paddysecondary-cropping pattern can be applied. The availability of enough water for farmers' palawija without motivation, land was left fallow. Water balance before planting was carried out and presented in Table 1.

Table1. Waterbalance of the Yeh Ho River watershed on average of the year 2000-2009

\begin{tabular}{|c|c|c|c|c|c|c|c|c|c|c|c|c|}
\hline \multirow{3}{*}{ Water Balance } & \multicolumn{12}{|c|}{ Water Fluctuation $(\mathrm{cm})$ in each month* } \\
\hline & $10 *$ & 11 & 12 & 1 & 2 & 3 & 4 & 5 & 6 & 7 & 8 & 9* \\
\hline & \multicolumn{4}{|c|}{$\begin{array}{c}\text { Rice } \\
\text { in Rainy Season }\end{array}$} & \multicolumn{4}{|c|}{$\begin{array}{c}\text { Rice } \\
\text { in } 1^{\text {st }} \text { Dry Season }\end{array}$} & \multicolumn{4}{|c|}{$\begin{array}{c}\text { Palawija } \\
\text { in } 2^{\text {nd }} \text { Dry Season }\end{array}$} \\
\hline Irrigation & 9 & 19 & 24 & 22 & 17 & 16 & 8 & 0 & -3 & -7 & -12 & -9 \\
\hline Evaporation & 17 & 15 & 14 & 15 & 14 & 14 & 14 & 14 & 13 & 13 & 15 & 15 \\
\hline Rainfall & 26 & 34 & 38 & 36 & 31 & 30 & 22 & 14 & 10 & 6 & 2 & 6 \\
\hline
\end{tabular}

Note: $* 10=$ October $; * 9=$ September

Source: BMG Bali, 2009 (data processed)

\subsection{The Combined Water Balance of the Yeh Ho River Watershed}

\section{a. Water balance combined with continuous irrigation}

The combined water balance of the region upstream, midstream and downstream watershed Yeh Ho with continuous irrigation, Table 2 shows the potential of water from rainfall of $426 \mathrm{~cm}$ and shallow groundwater of $803 \mathrm{~cm}$. Constantly or continuous irrigation $288 \mathrm{~cm}$ including tillage and the use of others as much as $626 \mathrm{~cm}$ indicated the availability of sufficient water for rice planting. April 2010 did not require any water, starting from May 2010 requires water until November 2010. When there was no water planting, it can be used for other purposes, namely in January 2010 and December 2010. However, the use of water for other purposes was recommended depending on the support of the local government and related agencies, as well as high commitment and dwascipline from irrigation water management actors so that conflicts of interest do not occur. The combined water balance of upstream, middle and downstream with continuous watering $(\mathrm{cm})$ was presented in table 2

Table2. Effect of continuous irrigation $(\mathrm{cm})$ on the water balance a combination of upstream, middle and downstream of the year 2010-2011

\begin{tabular}{|c|c|c|c|c|c|c|c|c|c|c|c|c|c|c|c|}
\hline \multirow{3}{*}{$\begin{array}{l}\text { Water } \\
\text { Balance }\end{array}$} & \multicolumn{15}{|c|}{ Water Fluctuation $(\mathrm{cm})$ in each month } \\
\hline & $12 *$ & 1 & 2 & 3 & 4 & 5 & 6 & 7 & 8 & 9 & 10 & 11 & 12 & $1 *$ & Total \\
\hline & \multicolumn{5}{|c|}{ Rice in $1^{\text {st }}$ Planting Season } & \multicolumn{4}{|c|}{$\begin{array}{c}\text { Rice in } 2^{\text {nd }} \\
\text { Planting Season }\end{array}$} & \multicolumn{5}{|c|}{$\begin{array}{c}\text { Rice in } 3^{\text {rd }} \\
\text { Planting Season }\end{array}$} & \\
\hline Reserve & 41 & 32 & 42 & 8 & 63 & 7 & 6 & 32 & 62 & 84 & 20 & 34 & 6 & 116 & 626 \\
\hline $\begin{array}{l}\text { Continous } \\
\text { Irrigation }\end{array}$ & 19 & 47 & 26 & 0 & 0 & 19 & 57 & 23 & 0 & 19 & 57 & 21 & 0 & 0 & 288 \\
\hline Evaporation & 23 & 22 & 26 & 1 & 31 & 21 & 18 & 12 & 9 & 25 & 20 & 27 & 43 & 21 & 914 \\
\hline Soil water & 55 & 68 & 61 & 7 & 55 & 18 & 60 & 46 & 58 & 79 & 59 & 53 & 15 & 98 & 803 \\
\hline Rainfall & 28 & 33 & 33 & 1 & 38 & 29 & 21 & 21 & 14 & 50 & 37 & 29 & 34 & 40 & 426 \\
\hline Total & & & & & & & & & & & & & & & 3057 \\
\hline
\end{tabular}

Note: $* 12=$ December; 1 = January.

Source: BMG Bali, 2009 (data processed)

\section{b. Water balance combined with irrigation once every 4 days}

The combined water balance with irrigation every 4 days, shows the potential of water from rainfall of $424.6 \mathrm{c} \mathrm{m}$ and shallow groundwater of $804.4 \mathrm{c} \mathrm{m}$. Experiencing evaporation $315.5 \mathrm{c} \mathrm{m}$. Irrigation 4 days once $252.2 \mathrm{c} \mathrm{m}$ including land management and other uses was as much as $661.3 \mathrm{c} \mathrm{m}$. For 
the combined water balance of the upstream, middle and downstream with irrigation, every 4 days shows the availability of water from rainfall and sufficient ground water. Water requirements for rice cultivation in December 2009 - early March 2010. March and April 2010 do not need water because the plants have been harvested, starting in May 2010 need water until November 2010 Table 3.

Table3. Effect of intermitten irrigation every 4 days on the water balance a combination of upstream, middle and downstream of the year 2000-2009

\begin{tabular}{|c|c|c|c|c|c|c|c|c|c|c|c|c|c|c|c|}
\hline \multirow{3}{*}{$\begin{array}{l}\text { Water } \\
\text { Balance }\end{array}$} & \multicolumn{15}{|c|}{ Water Fluctuation $(\mathbf{c m})$ in each month } \\
\hline & $12 *$ & 1 & 2 & 3 & 4 & 5 & 6 & 7 & 8 & 9 & 10 & 11 & 12 & 1* & Total \\
\hline & \multicolumn{5}{|c|}{$\begin{array}{c}\text { Rice in } 1^{\text {st }} \\
\text { Planting Season }\end{array}$} & \multicolumn{4}{|c|}{$\begin{array}{c}\text { Rice in } 2^{\text {nd }} \\
\text { Planting Season }\end{array}$} & \multicolumn{5}{|c|}{$\begin{array}{c}\text { Rice in } 3^{\text {rd }} \\
\text { Planting Season }\end{array}$} & \\
\hline Reserve & 41 & 42 & 46 & 81 & 63 & 7 & 16 & 35 & 62 & 84 & 29 & 32 & 6 & 116 & 660 \\
\hline $\begin{array}{l}\text { Every } 4 \\
\text { days } \\
\text { Irrigation }\end{array}$ & 19 & 37 & 22 & 0 & 0 & 19 & 47 & 20 & 0 & 19 & 47 & 23 & 0 & 0 & 253 \\
\hline Evaporation & 23 & 22 & 26 & 16 & 31 & 21 & 18 & 12 & 9 & 25 & 20 & 27 & 43 & 21 & 913 \\
\hline Soil water & 55 & 68 & 61 & 78 & 55 & 18 & 60 & 46 & 58 & 79 & 59 & 53 & 15 & 98 & 803 \\
\hline Rainfall & 28 & 33 & 33 & 19 & 38 & 29 & 21 & 21 & 14 & 50 & 37 & 29 & 34 & 40 & 426 \\
\hline Total & & & & & & & & & & & & & & & 3055 \\
\hline
\end{tabular}

\section{c. Water balance combined with irrigation once every 8 days}

The combined water balance with irrigation every 8 days, shows the potential of water from rainfall of $424.6 \mathrm{c} \mathrm{m}$ and shallow groundwater of $804.4 \mathrm{c} \mathrm{m}$. Evaporate a number of $315.5 \mathrm{c} \mathrm{m}$. Watering once every 8 days $221.4 \mathrm{c} \mathrm{m}$ including land management and other uses was $692.0 \mathrm{~cm}$. e combined water balance of upstream, middle and downstream irrigation every 8 days seems to indicate sufficient water availability. The need for water for rice cultivation in December 2009 - early March 2010. In April 2010, no water was needed, starting in May 2010 it needed water until November 2010. Water that can be used for other purposes in December and January. The combined water balance with irrigation every 8 days $(\mathrm{cm})$ was presented in Table 4.

Table4. Effect of intermitten irrigation every 8 days on the water balance a combination of upstream, middle and downstream of the year 2010-2011

\begin{tabular}{|c|c|c|c|c|c|c|c|c|c|c|c|c|c|c|c|}
\hline \multirow{3}{*}{$\begin{array}{l}\text { Water } \\
\text { Balance }\end{array}$} & \multicolumn{15}{|c|}{ Water Fluctuation $(\mathrm{cm})$ in each month } \\
\hline & 12* & 1 & 2 & 3 & 4 & 5 & 6 & 7 & 8 & 9 & 10 & 11 & 12 & $1 *$ & \multirow[b]{2}{*}{ Total } \\
\hline & \multicolumn{5}{|c|}{$\begin{array}{c}\text { Rice in } 1^{\text {st }} \\
\text { Planting Season }\end{array}$} & \multicolumn{4}{|c|}{$\begin{array}{c}\text { Rice in 2 } \\
\text { Planting Season }\end{array}$} & \multicolumn{5}{|c|}{$\begin{array}{c}\text { Rice in } 3^{\text {rd }} \\
\text { Planting Season }\end{array}$} & \\
\hline Reserve & 41 & 46 & 49 & 81 & 63 & 7 & 26 & 35 & 62 & 84 & 43 & 33 & 6 & 116 & 692 \\
\hline $\begin{array}{l}\text { Every } 8 \text { days } \\
\text { Irrigation }\end{array}$ & 19 & 34 & 18 & 0 & 0 & 19 & 37 & 20 & 0 & 19 & 33 & 23 & 0 & 0 & 222 \\
\hline Evaporation & 23 & 22 & 26 & 16 & 31 & 21 & 18 & 12 & 9 & 25 & 20 & 27 & 43 & 21 & 914 \\
\hline Soil water & 55 & 68 & 61 & 78 & 55 & 18 & 60 & 46 & 58 & 79 & 59 & 53 & 15 & 98 & 803 \\
\hline Rainfall & 28 & 33 & 33 & 19 & 38 & 29 & 21 & 21 & 14 & 50 & 37 & 29 & 34 & 40 & 426 \\
\hline Total & & & & & & & & & & & & & & & 3057 \\
\hline
\end{tabular}

\subsection{Water use for the Yeh Ho River Watershed}

Utilization of water in the Yeh Ho watershed area for 14 months (December 2009-January 2011) from upstream to downstream water supply for rice plants with a continuous irrigation system, the water used was $287 \mathrm{c} \mathrm{m}$ or $28,700 \mathrm{~m}^{3} \mathrm{ha}^{-1}$ leaving a reserve of water can used for other purposes was $627 \mathrm{c} \mathrm{m}$ or $62,700 \mathrm{~m}^{3} \mathrm{ha}^{-1}$.

Watering once every day consumes $252 \mathrm{~cm}$ water or $25,200 \mathrm{~m}^{3}$ ha ${ }^{-1}$ leaving a water reserve of $661 \mathrm{c} \mathrm{m}$ or $66,100 \mathrm{~m}^{3} \mathrm{ha}^{-1}$ and watering once every day consumes water $221 \mathrm{~cm}$ or $22,100 \mathrm{~m}^{3} \mathrm{ha}^{-1}$ leaving a water reserve of $692 \mathrm{c} \mathrm{m}$ or $69,200 \mathrm{~m}^{3} \mathrm{ha}^{-1}$. Overall, irrigation for 8 days uses less water and leaves more water reserves. The excess water from irrigation needs can be used deliberately between subaks as users and other users. The observations showed that for 14 months with continuous watering leaving $69 \%$ water, watering once every $72 \% 72$ days, watering once every day $76 \%$ Table 5 .

Table5. Effect of irrigation on water use and reserve, December 2010 - January 2011

\begin{tabular}{|l|l|l|l|l|l|l|l|l|l|}
\hline \multirow{2}{*}{ Watershed } & \multicolumn{2}{|l|}{ Water Fluctuation $(\mathbf{c m})$ in } \\
\cline { 2 - 10 } & $\begin{array}{l}\text { Evapo- } \\
\text { ration }\end{array}$ & $\mathbf{P 1}$ & Reserve & $\begin{array}{l}\text { Evapo- } \\
\text { ration }\end{array}$ & $\mathbf{P 2}$ & Reserve & Evaporation & P3 & Re-serve \\
\hline Upstream & 285 & 292 & 669 & 285 & 251 & 710 & 285 & 207 & 754 \\
\hline
\end{tabular}




\begin{tabular}{|l|l|l|l|l|l|l|l|l|l|}
\hline Midstream & 385 & 286 & 681 & 385 & 252 & 715 & 385 & 226 & 740 \\
\hline Downstream & 277 & 283 & 529 & 277 & 254 & 559 & 277 & 231 & 582 \\
\hline
\end{tabular}

\subsection{Persentage of water use Yeh Ho Watershed}

The percentage of use of water for irrigation by way of constantly having water reserves by $54 \%$. For irrigation purposes, continuous irrigation was $23 \%$ and evaporation was $23 \%$. For irrigation systems, once every 4 days evaporation was $23 \%$, Irrigation for tillage and plant needs was $23 \%$. The remaining water used was $57 \%$. For irrigation for 8 days, evaporation reaches $23 \%$ and for irrigation for 8 days, $17 \%$ was $60 \%$.

Percentage of water use (\%) shows that the utilization of water in the middle of the irrigation area with a continuous system that has a reserve of water used for other purposes was $50 \%$. For irrigation purposes, irrigation was $21 \%$ continuously and evaporation was $28 \%$. For irrigation systems, once every 4 days evaporation was $19 \%$, irrigation for tillage and crop needs was $23 \%$. The remaining water can be used as much as 53\%. With irrigation 8 days, evaporation reaches $17 \%$ and tillage $28 \%$. Other uses are $55 \%$. Percentage of water use in the downstream area with a continuous irrigation system has $49 \%$ water reserves. For irrigation purposes $26 \%$ and evaporation was $25 \%$.

Irrigation once every 4 days has evaporation of $26 \%$, for soil processing and plant needs by $23 \%$ with the remaining water as much as $51 \%$. For irrigation 8 days once evaporation reaches $26 \%$ and for irrigating land once every 8 days $21 \%$. The remaining water and other reserves are 53\% ( Table 6 ) .

Table6. Percentage of water used in three locations of watershed, December 2010 - January 2011

\begin{tabular}{|c|c|c|c|c|c|c|c|c|c|}
\hline \multirow[b]{2}{*}{ Watershed } & \multicolumn{9}{|c|}{ Water Use (\%) in } \\
\hline & $\begin{array}{l}\text { Evapo- } \\
\text { ration }\end{array}$ & P1 & $\begin{array}{l}\text { Re- } \\
\text { serve }\end{array}$ & $\begin{array}{l}\text { Evapo- } \\
\text { ration }\end{array}$ & $\mathbf{P 2}$ & $\begin{array}{l}\text { Re- } \\
\text { serve }\end{array}$ & $\begin{array}{l}\text { Evapo- } \\
\text { ration }\end{array}$ & $\mathbf{P 3}$ & $\begin{array}{l}\text { Re- } \\
\text { serve }\end{array}$ \\
\hline Upstream & 23 & 23 & 54 & 23 & 20 & 57 & 23 & 17 & 60 \\
\hline Midstream & 29 & 21 & 50 & 28 & 19 & 53 & 28 & 17 & 55 \\
\hline Downstream & 25 & 26 & 49 & 26 & 23 & 51 & 26 & 21 & 53 \\
\hline
\end{tabular}

\subsection{Percentage of combined water use}

Overall, the upstream, middle and downstream parts of the Yeh Ho River Watershed use a continuous irrigation system. Water used for irrigation includes soil treatment and water consumption for plants depleting $23 \%$ of water, experiencing evaporation of $26 \%$ and reserves, etc. $51 \%$. Using the irrigation system every 4 days, the water used for soil treatment and water consumption for plants consumes as much as $20 \%$ water, experiencing evaporation as much as $26 \%$ and reserves, etc. $54 \%$. Using an 8 day irrigation system, water used for soil treatment and water consumption for plants consumes $17 \%$ of water, has evaporation of $26 \%$ and reserves, etc. $57 \%$.

Thwas means that the percentage of evaporation between continuous irrigation and irrigation once every 4 days, irrigation once every 8 days has the same value. Continuous irrigation has a higher percentage of water consumption than irrigation 4 days and irrigation once every 8 days. The water supply has been increasing continuously watering, irrigation and watering 4 days 8 days d itunjukkan in Table 7.

Table7. Percentage of combine water used in Yeh Ho watershed, December 2009 - January 2011

\begin{tabular}{|l|c|c|c|}
\hline \multirow{2}{*}{ Watershed } & \multicolumn{3}{|c|}{ Water Use (\%) in } \\
\cline { 2 - 4 } & Evaporation & Irrigation & Reserve \\
\hline Continous Irrigation & 26 & 23 & 51 \\
\hline Every 4 days Irrigation & 26 & 20 & 54 \\
\hline Every 8 days Irrigation & 26 & 18 & 56 \\
\hline
\end{tabular}

The definition of stress day was "the number of days without inundation was calculated 2-3 days after the water on the surface of the rice fields was shredded" (Fagi, 2007). It was assumed that 2-3 days after macak-macak groundwater regime status of field capacity early (field capacity) at a voltage of $0.3 \mathrm{cb}$. Rice yield does not decrease until the maximum water stress was $0.8 \mathrm{cb}$. Bouman et.al (2007) uses a ground water depth of $15 \mathrm{~cm}$ as an indicator of re-irrigation. Water loss in wet-dry irrigation 
depends on the type of soil and the depth of the ground water surface. T anah textured loam with shallow ground water table $(10-40 \mathrm{~cm})$, relatively little water loss compared to dry wet soils pasiran.Pengairan applied since 10 days old rice plants after planting until two weeks before harvest, except in the week before and a week after flowering the rice fields are flooded with $3-5 \mathrm{~cm}$. Thwas method does not reduce grain yield, even under certain conditions grain yield actually increases (Bouman et.al , 2007).

\section{CONCLUSION}

Water supply in the watershed Yeh Ho with continuous irrigation, water used of $28,700 \mathrm{~m}^{3} \mathrm{ha}^{-1}$ leaving water reserves $62,700 \mathrm{~m}^{3} \mathrm{ha}^{-1}$. Irrigation once every 4 days drains $25,200 \mathrm{~m}^{3} \mathrm{ha}^{-1}$ of waterleaving $66,100 \mathrm{~m}^{3} \mathrm{ha}^{-1}$ of water reserves and 8 days of irrigation consumes $22,100 \mathrm{~m}^{3} \mathrm{ha}^{-1}$ leaving $69,200 \mathrm{~m}^{3}$ $\mathrm{ha}^{-1}$ of water. The observations showed that with continuous irrigation leaving $4.0 \%$ water, once every 4 days irrigation $15 \%$, once every 8 days irrigation $46.3 \%$.

The availability of water and its dwastribution was increasingly limited, so the use of water for agricultural irrigation especially paddy rice needs to be done wwasely so that excess irrigation water can be used to generate income through other businesses that mutually support the agricultural sector.

\section{ACKNOWLEDGMENT}

Infinite thanks say the author conveyed to: Prof. Dr. Djoko Prajitno, Dr. Abdul Syukur, and Dr. Heru Hendrayana, as the promoter s who has Contributed valuable thoughts, advice, encouragement, critic i sm and suggestions. The DG of the Indonesian Agency for Research and Development (IAARD) on my doctorate scholarship at the Gadjah Mada University, Yogyakarta. $T$ he director of the Indonesian Center for Assessment Institute of Agricultural Technology, and the Head of Bali Assessment Institute of Agricultural Technology who have given the opportunity for me to continue my doctoral stud $y$.

\section{REFERENCES}

[1] Asdak, C. 1995. Hydrology and Management of the Alira River Region. Gajah Mada University Press. Yogyakarta.

[2] Arsana, IGKD, S. Yahya, AP . Lontoh \& H. Pane 2003. Relationship between early inundation and redox potential, ethylene production and its effect on the growth and yield of rice (Oryza sativa) of the Tabela system. Buletin Agronomy Vol. 31 No. 2

[3] Arsana, IGKD 2006. The role of new high-yielding rice varieties in supporting crop-livestock farming in Subak Delod Bakas, Klungkung, Bali. On the inside: (eds.). Suprihatno, B., ( eds .). Rice technology innovation. Towards sustainable rice self-sufficiency. Book Two. Crops Research and Development Center Pangan.Hal: 477-488.

[4] Arwata, 2003. The challenge of subak in the effort to preserve rice culture in Bali. In Subak and Kertamasa. 113-124.

[5] Batie, S. 1993. Water Resources, Agriculture and the Environment. Inside : Environment and Agriculture p. 64-115. Winrock International.

[6] Bouman, BAM, R. M Lampayan \& TP Toung. 2007. Water management in irrigated rice: Coping with water Scarcity. International Rice Research Institude. Los Banos. Philippines. 50 p.

[7] Buckman, HO \& N.C. Brady 1969. The nature and properties of soils. Translated by: Soegiman. Bhratara Karya Aksara, Jakarta

[8] Cassman, KG, S. Peng, DC Olk, JK Ladha, W. Reichardt, A. Dobermann, U. Singh. 1998. Opportunities for increased nitrogen-use efficiency from improved resource management in irrigated rice systems. Field Crop Res. 56: 7-39.

[9] Center for Land and Agro-climate Research and Development. 2000. Atlas of Direction of Indonesian Agricultural Spatial Planning. Center for Research and Development of Land and Agro-climate, Agricultural Research and Development Agency.

[10] Center for Land and Agro-climate Research and Development.2001. Atlas of Indonesian Land Exploration Resources. Center for Land and Agro-climate Research and Development, Agricultural Research and Development Agency .

[11] Central Bureau of Statwastics. 2010. Statwastics of Indonesia. Jakarta Central Bureau of Statwastics.

[12] Chang. 1968. Climate and Agriculture. An Ecological Survey. Aldine Publwashing Company . Canada.

[13] Chiu, WTF, ZS Chen, WC Cosico \& FB Aglibut. 2000. Management of Slope Lands in Asia-Pacific Region. Food \& Fertilizer Technology Center for the Asian and Pacific Region. Taipei, Taiwan, ROC. 90 p. 
[14] De Datta, SK 1981. Principles and Practices of Rice Production. John Wiley and Sons, New York, Toronto. $618 \mathrm{p}$.

[15] Public Works Department. 2008. Bali Penida River Watershed. Directorate General of Water Resources, Minwastry of Public Works.

[16] Deed of Bali. 2007. Guidelines for Implementing the 2007 National Rice Production Increase Movement in the Province of Bali. Bali Province Food Crop Agriculture Office. Bali Provincial Government, Food Crop Agriculture Office, 2007.

[17] Fagi, AM \& SA Sanusi, W. 1983. Improving Irrigation Water Efficiency with Food Crop Cultivation Techniques and Irrigation Techniques. In the Minutes of the Rice Research Workshop, Cibogo, Bogor 2224 March 1983.

[18] Fagi, AM 1998. Water management to improve fertilizer efficiency. In Proceedings of the Workshop on Fertilizer Efficiency, Soil Research Center, Bogor. 209-220.

[19] Fagi, AM, Abdullah \& Kartaatmaja, S. 2002. The Role of Indonesian Rice as a Modern Rice Genetic Resource. In the Rice Culture Proceedings of the Indonesian Padi Foundation, p. 33-43.

[20] Fagi, AMCP Mamaril \& M.Syam 2009 Green Revolution. Role and Dynamics of Research Institutions. Indonesian Center for Rice Research 34 pages .

[21] Fagi, AM 2007. Arrange Management of Water Resources for the Future of Agriculture. Food Crops Science, Vol. 2, 1-11.

[22] Fagi, AM 2006. Irrigation Water Management at the Farming Level : A Case in Barugbug, Jatiluhur. Food Crops Science, Vol. 1, No.1, p. 41-56.

[23] FAO [Food and Agriculture Organization] 1998. Crop evaporation guidelines for computing crop water requirements. Irrigation and drainage. FAO. Rome 300p.

[24] Hall Research Agro-climate and Hydrology.2003. Atlas of Agricultural Climate Resources in Indonesia. Agro-climate and Hydrology Research Center, Center for Agriculture and Agro-climate, IAARD.

[25] Huke, R. 1976. Geography and Climate of Rice. In Climate and Rice. IRRI, Los Banos, Laguna, Philippines, pp. 31-50.

[26] Kurniigsih, A. 2010. When 5000 ha of Competing Water Paddy Fields with 4000 Starred Hotel Rooms. Udayana University Lokatulwas, Denpasar.

[27] Nasir AN, \& S. Effendy. 1999. Water Balance Concepts for Determination of Patterns

[28] Noordwijk, NP Fahmuddin Agus, Didik Suprayogo, Kurniatun Hairiah, Gamal Pasya, Bruno Verbwast and Farida. 2004. The Role of Agroforestro in Watersheds (DAS). Agrivita, Journal of Agricultural Sciences. 139 things.

[29] Pitana, IG 2003. Rice Culture, Subak System and Tourwasm Development in Bali. In the Subak and Kertamasa, p. 113-124.

[30] Purbawa, IGA, \& ING Wiryajaya 2009. Normal Spatial Analyswas of Monthly Groundwater Availability in the Province of Bali. Meteorology and Geophysics Bulletin. Center for Meteorology and Geophysics Region III Denpasar. Vol. 5 No. June 2

[31] Soil and Environmental Science Concentration in Denpasar - Bali Agroecotechnology Study Program . Udayana University

[32] Sharma, PS, G. Pantuwan, KT Ingram \& SK De Datta. 1994. Rainfed Lowland rice roots: soil and hydrological effects. Inside : Kirk GJD ( $e d s$ ). Rice roots: nutrient and water use. Selected papers from the international rice research conference. International Rice Research Institute. Los Banos. Lagoon Philippines. p: 55-66.

[33] Suadnya, IGG 1997. Development and Maintenance of Irrigation Subak On the inside : Pitana (eds): Traditional Irrigation Systems Subak in Bali, A Canang Sari. case 94-108.

[34] Sosrodarsono and Takeda. 2003. Hydrology for Watering. Pradita Paramita Publwasher Jakarta

[35] Subagyono, K. \& E. Sumarini. 2007. Agriculture Adaptation to Climate Change. Monthly Bada Meteorology and Geophysics (BMG) Seminar. IPB, Dramaga, Bogor, 28 June 2007.

[36] Suyarto R and T Kusmawati. 2016. Laboratory of Land Resource Evaluation

Citation: Made J. Mejaya \& I G.K. Dana Arsana, "Water Balance in Rice Intensification Program in Bali Province, Indonesia” International Journal of Research Studies in Agricultural Sciences (IJRSAS), 2020; 6(4), pp. 31-39,http://dx.doi.org/10.20431/2454-6224.0604005

Copyright: (C) 2020 Authors. This is an open-access article distributed under the terms of the Creative Commons Attribution License, which permits unrestricted use, distribution, and reproduction in any medium, provided the original author and source are credited. 